\title{
First report of G143A strobilurin resistance in Cercospora beticola in sugar beet (Beta vulgaris) in Poland
}

\author{
Jacek Piszczek $^{1} \cdot$ Katarzyna Pieczul $^{2} \cdot$ Agnieszka Kiniec $^{1}$
}

Received: 28 June 2017/ Accepted: 16 August 2017/Published online: 18 August 2017

(c) The Author(s) 2017. This article is an open access publication

\begin{abstract}
Cercospora leaf spot (CLS) caused by the fungus Cercospora beticola is the most common and destructive disease of sugar beet in Poland. Strobilurin (Quinone outside inhibitors-QoI) fungicides are widely used for CLS control. In Poland for several years, a gradual increase in QoI tolerance has been observed. In 2015, most of the tested isolates $(56 \%)$ collected from several independent locations were able to grow in a PDA medium supplemented with $1 \mu \mathrm{g} / \mathrm{ml}$ of azoxystrobin. An additional test showed that the $\mathrm{EC}_{50}$ value for the most resistant isolates was $\geq 100 \mu \mathrm{g} / \mathrm{ml}$, while for the sensitive ones it was $\leq 0.01 \mu \mathrm{g} / \mathrm{ml}$. The results of cytochrome b partial DNA sequencing revealed that all resistant isolates contained single guanine to cytosine substitution $(\mathrm{G} / \mathrm{C})$, predicting the conversion of glycine to alanine at the 143 codon position (G143A). To our knowledge, this is the first report in a peer-reviewed paper on G143A mutation determining the strobilurin resistance of $C$. beticola in Poland.
\end{abstract}

Keywords Cercospora leaf spot - Cercospora beticola . QoI resistance

Katarzyna Pieczul

k.pieczul@iorpib.poznan.pl

Jacek Piszczek

J.Piszczek@iorpib.poznan.pl

Agnieszka Kiniec

agnieszkakiniec@onet.pl

1 Regional Experimental Station, Institute of Plant Protection National Research Institute, ul. Pigwowa 16, 87-100 Toruń, Poland

2 Department of Mycology, Institute of Plant Protection National Research Institute, ul. Węgorka 20, 60-318 Poznań, Poland
Cercospora leaf spot (CLS) caused by the fungus Cercospora beticola Sacc. is one of the most common and destructive foliar diseases of sugar beet (Beta vulgaris) worldwide (Skaracis et al. 2010). The disease leads to premature death of leaves, and by reducing the assimilation area it causes a significant loss of root yield and diminished sucrose content (Skaracis et al. 2010). In Poland, the disease occurs annually, but its economic impact is particularly noticeable during years with warm and rainy summer and early autumn. In Poland, CLS is mainly controlled with single-site fungicides, such as sterol demethylation inhibitors (DMI) or quinone outside inhibitors (QoI) fungicides, used as single or mixed preparations. Unfortunately, frequent application of this class of fungicides leads to selective pressure and the development of resistance in plant pathogens (Ma and Michailides 2005).

QoI fungicides (strobilurins) are widely used in agricultural production because of their wide antifungal spectrum and low phytotoxicity. They act by binding the quinol oxidation site of cytochrome $b_{1}$ protein. It disrupts electron transfer between cytochrome $\mathrm{b}$ and $\mathrm{c}_{1}$ complexes and leads to ATP production deficiency in sensitive fungi (Bartlett et al. 2002; Fisher and Meunier 2008). The QoI resistance is usually conferred by single-point mutation in mitochondrial cytochrome $\mathrm{b}$ gene (cytb). Amino acid exchange from glycine to alanine at the 143 codon position (G143A) was detected as the main source of QoI resistance in many plant pathogenic fungi (Birla et al. 2012; Bolton et al. 2012; Jiang et al. 2009; Obuya and Franc 2016). Substitution phenylalanine to leucine (F129L) and glycine to arginine (G137R) are less common (Fisher and Meunier 2008).

Poland is one of the most important sugar beet producers in the European Union (http://ec.europa.eu/eurostat). Due to the significance of sugar beets in agricultural production, 
it is very important to know and monitor the occurrence of QoI-resistant isolates. The aim of the study was to detect the presence of mutations leading to QoI resistance in $C$. beticola in Poland.

Sugar beet leaves infected with $C$. beticola were randomly sampled from several fields located mainly in central (Dobrzelin, Kruszwica), eastern (Krasnystaw, Werbkowice) and western (Kluczewo) Poland in August and September 2015. The fields were owned by Krajowa Spółka Cukrowa S.A. and the crops were protected according to Polish plant protection recommendations. Individual, surficially sterilised leaf spot lesions were placed and grown on a PDA (Potato Dextrose Agar; Oxoid Ltd, Basingstoke, UK) medium. After 1 week of incubation at $21^{\circ} \mathrm{C}$, the emerging $C$. beticola cultures, identified by colony morphological features, were transferred into a new PDA medium. In total, 126 C. beticola isolates were obtained (Dobrzelin 12, Kruszwica 36, Krasnystaw 23, Werbkowice 25, Kluczewo 18, others locations 12 isolates). All of the cultures were incubated for 2-3 weeks at $21{ }^{\circ} \mathrm{C}$. In order to assess strobilurin sensitivity mycelial plugs $\left(0.5 \mathrm{~cm}^{2}\right)$ taken from the edge of the colonies were placed on a PDA medium amended with $1 \mu \mathrm{g} / \mathrm{ml}$ azoxystrobin (Amistar 250 SC; Syngenta, Basel, Switzerland) and on PDA without amendment. The percentage of growth inhibition was measured according to the method described by Bugbee (1995). In order to estimate the $\mathrm{EC}_{50}$ values (half maximal effective concentration), selected isolates were additionally tested on the PDA medium containing azoxystrobin (Sigma-Aldrich; Saint Louis, USA) at a concentration of: $0,0.01,0.1,0.5,1,5,10,20,50$ and $100 \mu \mathrm{g} / \mathrm{ml}$. To block the alternative oxidation pathway each medium was supplemented with $100 \mu \mathrm{g} / \mathrm{ml}$ salicylhydroxamic acid (SHAM; Sigma-Aldrich). The fungicide was dissolved in acetone at $100 \mathrm{mg} / \mathrm{ml}$ and diluted to $10 \mathrm{mg} / \mathrm{ml}$ in distilled water before being added to the medium. The samples were incubated for 7 days at $21^{\circ} \mathrm{C}$. The mean EC 50 values of the tested isolates were calculated. The assays were repeated three times.

Ten resistant $\left(\mathrm{EC}_{50}\right.$ value $\left.\geq 10-100 \mu \mathrm{g} / \mathrm{ml}\right)$ and three sensitive isolates $\left(\mathrm{EC}_{50}\right.$ value $\left.\leq 0.01 \mu \mathrm{g} / \mathrm{ml}\right)$ were chosen for cytochrome b DNA sequence analysis. Total genomic DNA was extracted from fresh mycelium using a Plant/ Fungi DNA isolation Kit (Norgen Biotek Corp.; Thorold, Canada), following the instruction of the manufacturer. Fresh mycelium (100 mg) growing for 2-3 weeks on a PDA medium was gently scraped with a lancet and transferred into a $1.5 \mathrm{ml}$ Eppendorf tube. The samples were precisely macerated with a micropestle, and sterile quartz sand was added. The quantity and quality of the extracted DNA was measured using a NanoDrop spectrophotometer (Thermo Fisher Scientific; Waltham, USA). 20 ng/ $\mu$ l DNA solutions were prepared for each probe and preserved at
$-20{ }^{\circ} \mathrm{C}$. A DNA fragment of cytochrome $b$ gene was PCR amplified with cytbSF and cytbSR primers (Malandrakis et al. 2011), followed by Sanger sequencing of the product obtained. The PCR mixture contained $40 \mathrm{ng}$ of template DNA, $1 \mu \mathrm{M}$ of each primer, $1 \times$ Master MIX (Thermo Fisher Scientific). All reactions were carried out in total volumes of $20 \mu \mathrm{l}$. The PCR thermal cycling protocol was as follows: initial denaturation at $95{ }^{\circ} \mathrm{C}$ for $3 \mathrm{~min}$, then 40 cycles of denaturation for $30 \mathrm{~s}$ at $95{ }^{\circ} \mathrm{C}$, annealing for $30 \mathrm{~s}$ at $55^{\circ} \mathrm{C}$, and elongation for $60 \mathrm{~s}$ at $72{ }^{\circ} \mathrm{C}$, followed by the final extension step for $5 \mathrm{~min}$ at $72{ }^{\circ} \mathrm{C}$. All PCR reactions were conducted in a Mastercycler ep gradient $\mathrm{S}$ thermal cycler (Eppendorf; Hamburg, Germany). The amplification products were separated by gel electrophoresis in $1.5 \%$ agarose gel in $0.5 \times$ TBE (Thermo Fisher Scientific) with Midori Green (Nippon Genetics; Dueren, Germany) staining and visualised under UV $360 \mathrm{~nm}$ light. The PCR products were commercially Sanger-sequenced at Genomed S.A. (www.genomed.pl).

Most of the tested isolates $(56 \%)$ collected from several independent locations (Dobrzelin 6, Kruszwica 15, Krasnystaw 17, Werbkowice 17, Kluczewo 8, others locations 7 isolates) were able to grow (growth inhibition percentage $>50 \%$ ) on the medium supplemented with $1 \mu \mathrm{g} / \mathrm{ml}$ azoxystrobin. An additional test showed that the $\mathrm{EC}_{50}$ for the selective, resistant isolates was $\geq 10-100 \mu \mathrm{g} / \mathrm{ml}$, while for the sensitive ones it was $\leq 0.01 \mu \mathrm{g} / \mathrm{ml}$. The sequencing analysis of the partial cytochrome $b$ gene revealed that all of the ten tested resistant isolates contained single guanine to cytosine $(\mathrm{G} / \mathrm{C})$ substitution predicting the conversion of glycine to alanine at the 143 codon position (G143A). This mutation was not observed in any of the three sensitive isolates tested. F129L or other mutations were not found in any items. The partial DNA sequences of cytochrome $b$ strobilurin-resistant and strobilurin-sensitive isolates were deposited in the NCBI database (GenBank Accession Nos. MF327259 and MF327260). The obtained C. beticola cytochrome b partial DNA sequences exhibited $100 \%$ homology to the $C$. beticola cytochrome $\mathrm{b}$ sequence (GenBank Accession Nos. JQ360626 and JQ360628).

In the USA, QoI fungicides have been used for management of sugar beet diseases since the late 1990s (Briere et al. 2003; Secor et al. 2010); in Europe and Polandapproximately since the late 2000s. There were no reports on QoI field resistance in the USA and Greece until 2011, and in France until 2012 (Birla et al. 2012; Malandrakis et al. 2011; Secor et al. 2010). The first QoI-resistant isolates of $C$. beticola containing the substitution of glycine to serine at the 143 codon position (G143S) and others were detected under artificial conditions only (Malandrakis et al. 2006). However, due to the widespread use of strobilurin in CLS management QoI resistance is developing rapidly in many sugar beet growing areas. Nowadays QoI-resistant 
field isolates of $C$. beticola with the G143A mutation have been detected in many sugar beet growing areas in Europe (mostly the Mediterranean area) and the USA (Bolton et al. 2012; Birla et al. 2012; Obuya and Franc 2016). Recently the F129L mutation was identified as a moderate source of QoI resistance in C. beticola isolates obtained from table beets in the USA (New York) (Vaghefi et al. 2016). Until 2015 the G143A mutation was not reported in Poland, but increased strobilurin tolerance was observed (Pieczul and Perek 2013). The phenomenon was attributed to the additional supply of energy due to increased alternative oxidase (AOX) activity or due to other reasons (Pieczul and Perek 2015). Previous studies indicated that AOX can be induced by fungicides causing ubiquinone inhibition (QoI), what increased survival of fungi under QoI treatment (Wood and Hollomon 2003).

In comparison with warmer sugar beet growing areas, in Poland the increase in QoI-resistant C. beticola isolates was delayed. We found it as a result of less frequent application of fungicides for sugar beet protection in this climate zone. The data confirmed resistant G143A phenotypes of $C$. beticola isolates collected from fields at independent locations. To our knowledge, this is the first report in a peer-reviewed paper of the C. beticola strobilurin resistance induced by G143A mutation in Poland. To conclude, the research findings indicate that QoI fungicides can be less efficient for CLS control in Poland and new disease management strategies must be implemented. The choice of fungicides for CLS control in Poland is limited mainly to DMI and QoI, which makes effective crop protection more difficult.

\section{Compliance with ethical standards}

Conflict of interest The authors declare that they have no conflict of interest.

Open Access This article is distributed under the terms of the Creative Commons Attribution 4.0 International License (http://crea tivecommons.org/licenses/by/4.0/), which permits unrestricted use, distribution, and reproduction in any medium, provided you give appropriate credit to the original author(s) and the source, provide a link to the Creative Commons license, and indicate if changes were made.

\section{References}

Bartlett DW, Clough JM, Godwin JR, Hall AA, Hamer M, ParrDobrzanski B (2002) The strobilurin fungicides. Pest Manag Sci 58:649-662. doi:10.1002/ps.520

Birla K, Rivera-Varas V, Secor GA, Khan M, Bolton MD (2012) Characterization of cytochrome $b$ from European field isolates of
Cercospora beticola with quinone outside inhibitor resistance. Eur J. Plant Pathol 134:475-488. doi:10.1007/s10658-012-0029$\mathrm{y}$

Bolton MD, Rivera V, Secor G (2012) Identification of the G143A mutation associated with QoI resistance in Cercospora beticola field isolates from Michigan, United States. Pest Manag Sci 69:35-39. doi:10.1002/ps.3358

Briere SC, Franc GD, Kerr ED (2003) Fungicide sensitivity characteristics of Cercospora beticola isolates recovered from the High Plains of Colorado, Montana, Nebraska, and Wyoming. 1. Benzimidazole and triphenyltin hydroxide. J Sugar Beet Res $38: 111-120$

Bugbee WM (1995) Cercospora beticola tolerant to triphenyltin hydroxide. J Sugar Beet Res 32:167-174

Fisher N, Meunier B (2008) Molecular basis of resistance to cytochrome bc1 inhibitors. FEMS Yeast Res 8:183-192. doi:10.1111/j.1567-1364.2007.00328

Jiang J, Ding L, Michailides TJ, Li H, Ma Z (2009) Molecular characterization of field azoxystrobin-resistant isolates of Botrytis cinerea. Pestic Biochem Physiol 93:72-76. doi:10.1016/j. pestbp.2008.11.004

Ma Z, Michailides TJ (2005) Advances in understanding molecular mechanisms of fungicide resistance and molecular detection of resistant genotypes in phytopathogenic fungi. Crop Prot 24:853-863. doi:10.1016/j.cropro.2005.01.011

Malandrakis AA, Markoglou AN, Nikou DC, Vontas JG, Ziogas BN (2006) Biological and molecular characterization of laboratory mutants of Cercospora beticola resistant to Qo inhibitors. Eur J Plant Pathol 116:155-166. doi:10.1007/s10658-006-9052-1

Malandrakis AA, Markoglou AN, Nikou DC, Vontas JG, Ziogas BN (2011) Molecular diagnostic for detecting the cytochrome $b$ G143S-QoI resistance mutation in Cercospora beticola. Pestic Biochem Physiol. doi:10.1016/j.pestbp.2011.02.011

Obuya JO, Franc GD (2016) Molecular analysis of Cercospora beticola isolates from strobilurin resistence from the Central High Plains, USA. Eur J Plant Pathol 146:817-827. doi:10.1007/ s10658-016-0959-X

Pieczul K, Perek A (2013) Fungicide resistance of Cercospora beticola isolates collected from Wielkopolska region. Progress Plant Prot 53(4):796-800. doi:10.14199/ppp-2013-027

Pieczul K, Perek A (2015) The reasons of strobilurin resistance of Cercospora beticola (cercospora leaf spot) isolates in Wielkopolska region. Progress Plant Prot 55(1):45-48. doi:10. 14199/ppp-2015-008

Secor GA, Rivera VV, Khan MFR, Gudmestad NC (2010) Monitoring fungicide sensitivity of Cercospora beticola of sugar beet for disease management decisions. Plant Dis 94:1272-1282. doi:10. 1094/PDIS-07-09-0471

Skaracis GN, Pavili OI, Biancardi E (2010) Cercospora leaf spot disease of sugar beet. Sugar Tech 12(3-4):220-228. doi:10.1007/ s12355-010-0055-z

Vaghefi N, Hay F, Kikkert JR, Pethybridge SJ (2016) Genotypic diversity and resistance to azoxystrobin of Cercospora beticola on processing table beet in New York. Plant Dis 100(7):1466-1473. doi:10.1094/PDIS-09-15-1014-RE

Wood PM, Hollomon DW (2003) A critical evaluation of the role of alternative oxidase in the performance of strobilurin and related fungicides acting at the Qo site of complex III. Pest Manag Sci 59(5):499-511. doi:10.1002/ps.655 